\title{
eCOti
DiAno
}

Revista Mídia e Cotidiano

ISSN: 2178-602X

Artigo Seção Livre

Volume 14, Número 1, jan-abr de 2020

Submetido em: 25/09/2019

Aprovado em: 03/02/2020

\section{Eu cresci assim: representações de gênero e empoderamento feminino nas telenovelas Gabriela e Tieta}

\section{I grew up like this: gender representations and female empowerment in Gabriela and Tieta}

\author{
Valtyennya Campos PIRES ${ }^{1}$ \\ Robéria Nádia Araújo NASCIMENTO²
}

\begin{abstract}
Resumo
A abordagem problematiza as adaptações televisivas Gabriela e Tieta, baseadas nas obras homônimas de Jorge Amado, a fim de discutir as representações de gênero que auxiliam a compreensão das singularidades do feminino. As tramas evidenciam posturas estigmatizadas (GOFFMAN, 1988) que marcam as vivências das personagens-título e as violências simbólicas e não simbólicas que perpassam as personagens periféricas. Do ponto de vista metodológico, uma Análise de Narrativas (MOTTA, 2013) fundamenta os fragmentos observados. Os resultados sugerem que as teleficções promovem saberes culturais em meio às trajetórias femininas no combate à discriminação. Nesse sentido, indicam caminhos para se pensar as telenovelas como espaços de reprodução de situações de erotização, subalternidade e sexismo da mulher negra.
\end{abstract}

Palavras-chave: Gabriela e Tieta. Representações de gênero. Empoderamento feminino. Estigmas sociais.

\begin{abstract}
The approach problematizes the television adaptations Gabriela and Tieta, based on the homonymous works by Jorge Amado, in order to discuss the gender representations that help the understanding of feminine singularities. The plots show stigmatized postures (GOFFMAN, 1988) that mark the experiences of the title characters and the symbolic and non-symbolic violence that pervade the peripheral characters. From the methodological point of view, a Narrative Analysis (MOTTA, 2013) underlies the observed fragments.

\footnotetext{
${ }^{1}$ Possui graduação em Jornalismo, pela Universidade Estadual da Paraíba. Desenvolve trabalhos sobre Televisão, Gênero e Mídia, Religião e Mídia e Gênero e Educação. Integrante do Grupo de Pesquisa Comunicação Cultura e Desenvolvimento, na linha de pesquisa Mídia e Estudos Culturais, cadastrado no CNPq. E-mail: valtycampos@gmail.com. ORCID: 0000-0002-0294-8968.

${ }^{2}$ Doutora em Educação pela Universidade Federal da Paraíba. Professora Associada do Departamento de Comunicação Social (UEPB). Professora do Programa de Pós-Graduação em Formação de Professores (PPGFP/UEPB), vinculada à Linha de Pesquisa Ciências, Tecnologias e Formação Docente. Integrante dos Grupos de Pesquisa Comunicação, Cultura e Desenvolvimento e Comunicação, Memória e Cultura Popular (DECOM/UEPB). E-mail: rnadia@terra.com.br. ORCID: 0000-0002-1806-0138.
} 
The results suggest that telephoning promotes cultural knowledge in the midst of women's trajectories in the fight against discrimination. In this sense, they indicate ways to think of telenovelas as spaces for the reproduction of eroticization, subordination and sexism of black women.

Keywords: Gabriela and Tieta. Gender representations. Female empowerment. Social stigmata.

\section{Introdução}

Este estudo deriva de uma pesquisa acadêmica (PIBIC/UEPB, 2017/2018) que privilegiou a análise das questões do feminino inscritas nas narrativas televisivas inspiradas nas obras homônimas de Jorge Amado. Portanto, este trabalho se refere às adaptações para a TV da literatura do escritor baiano, desconsiderando observações comparativas às obras impressas originais. Sistematizamos a discussão de gênero que se interpõe à trajetória das protagonistas Gabriela e Tieta, incluindo nas observações as personagens periféricas, uma vez que os romances adaptados tratam de questões sociológicas pertinentes ao tempo presente. Uma delas diz respeito à construção de gênero numa perspectiva aberta às conquistas do feminino, e não como resultante de predestinações. Por isso, o título ${ }^{3}$ desta abordagem e alguns subtítulos contrariam a trilha de abertura da novela Gabriela para sugerir os sentidos de impermanência e transformação inerentes à vida social e aos indivíduos: não "nascemos, mas nos tornamos" mulheres, profissionais, sujeitos ativos no mundo.

Dessa forma, a violência simbólica e física que permeia tais questões são pretextos para se refletir sobre a objetificação da mulher, especialmente negras e mulatas (como ilustram as personagens), muito comum nas sociedades patriarcais com suas relações discriminatórias. Há que se considerar que os contextos retratados nas tramas amadianas narram dilemas que se repetem na contemporaneidade, visto que muitos dramas vivenciados pelas personagens ainda ocorrem no atual momento histórico para além de "coisas de novela".

\footnotetext{
${ }^{3}$ Referência à canção "Modinha para Gabriela" (1975), composta por Dorival Caymmi e popularizada na voz de Gal Costa: "Quando eu vim pra esse mundo... Eu não atinava em nada. Hoje eu sou Gabriela, Gabriela he!, meus camaradas. Eu nasci assim, eu cresci assim... Eu sou mesmo assim... Vou ser sempre assim Gabriela, sempre Gabriela!’ [...].
} 
A atemporalidade é, também, uma característica a ser ressaltada nas obras do escritor, pois, segundo Araújo (2003), na literatura amadiana a sociedade se reconhece em sua vez e voz, já que "o povo é ator e não mais assunto, assumindo foros de consciência de seu estar num mundo de opressões e injustiças" (ARAÚJO, 2003, p. 15). Isso respalda a ideia de que Jorge Amado, como autor e militante vanguardista das questões socioculturais, torna-se relevante para entender a conjuntura atual, na qual as mulheres ainda são discriminadas não apenas por gênero, como por questões de cor da pele, e que, apesar desse contexto, continuam defendendo suas causas de modo resiliente e trabalhando em prol de um mundo mais justo. Assim, as heroínas transgressoras dos enredos, como Gabriela e Tieta, além das coadjuvantes, representam muitas mulheres brasileiras, sobretudo, as nordestinas, que não se deixam abater diante das relações patriarcais e dos estereótipos subalternos.

O patriarcado, para Millett (1969), "pode ser entendido como uma instituição social que se caracteriza pela dominação masculina nas sociedades contemporâneas em várias instituições sejam elas políticas, econômicas, sociais ou familiar” (MILLETT, 1969, p. 58). Nessa perspectiva, as teleficções Gabriela e Tieta, oriundas das obras Gabriela, Cravo e Canela (1958) e Tieta do Agreste (1977), podem promover uma reflexão acerca das questões femininas que as envolvem.

Nagamini (2004), ao justificar o deslocamento do texto literário para a tela da TV, aponta os ganhos estéticos das narrativas em função dos recursos imagéticos mobilizados. $\mathrm{O}$ audiovisual é mais atrativo na equivalência dos cenários idealizados pelos escritores, favorecendo a disseminação e a compreensão temática das tramas, ainda mais quando consideramos uma população com hábitos de leitura insuficientes que impedem o acesso aos textos originais.

Isso posto, cumpre destacar que as telenovelas são observadas aqui à luz da Análise de Narrativas que, de acordo com Motta (2013), engloba um conjunto de procedimentos de leitura criteriosa e em constante refinamento, contemplando a descrição sistemática de conteúdos temáticos presentes nos produtos da comunicação na busca por significações. Narrativas são ações enunciadas pelos sujeitos interlocutores que mobilizam performances linguísticas para convencer as audiências. De acordo com o autor, "na impossibilidade de se observar o ato em si, estudam-se as marcas presentes nos 


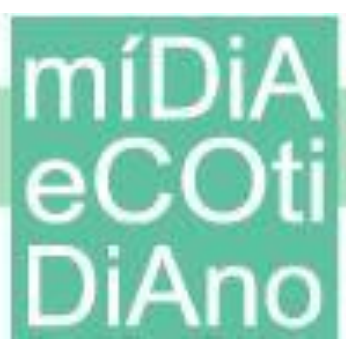

textos e a correlação entre os interlocutores, tanto no processo produtivo quanto no processo de leitura e interpretação" (MOTTA, 2013, p. 11). Neste enfoque, os textos se referem aos diálogos e situações destacadas nas tramas com a finalidade de ilustrar a fundamentação teórica.

A apresentação da análise, aqui sintetizada em razão dos limites de um artigo, é fundamentada em três momentos. No primeiro, abordamos o gênero ficção e o formato da telenovela para pensarmos qual é o papel desse produto cultural na reprodução de estereótipos do feminino. No segundo, discutimos as concepções de gênero e de representações. Por último, os fragmentos das telenovelas visam contextualizar o empoderamento feminino retratado na ficção a fim de incitar a compreensão da problemática.

\section{Eu (não) nasci assim, eu cresci assim: as telenovelas e os propósitos ficcionais}

A ficção televisiva, sobretudo a teledramaturgia, possui um papel importante no debate de temas que permeiam diversos grupos sociais. Além de reproduzir estereótipos, as telenovelas também os contestam produzindo novas identidades e novos jeitos de pensar o mundo, gerando debates e ressonâncias sobre os conteúdos das histórias.

Lopes (2010) explica que as telenovelas articulam e estreitam as discussões acerca do mundo a partir de temáticas de interesse público:

As narrações televisivas parecem responder a uma necessidade difusa e universal de ouvir e de ver; criam e articulam temas e interesses fortes - elementares, básicos, ou melhor, primários, da vida cotidiana, do estar no mundo: o bem e o mal, o amor e o ódio, a família, a amizade, a violência, a justiça, a doença e a saúde, a felicidade e a desgraça, os sonhos e os medos (LOPES, 2010, p. 10).

Segundo Rebouças (2009), as telenovelas constituem um gênero televisivo independente, que lideram a audiência em diferentes regiões, segmentos sociais, sexo e faixas etárias, sendo "um excelente meio para a difusão de conteúdos culturais e educativos junto às populações carentes de alternativas, como é o caso de grande parcela da população brasileira" (REBOUÇAS, 2009, p. 1). 
Surgiram no Brasil em 1951, um ano após a televisão ter sido inaugurada no país. A primeira trama foi exibida pela TV Tupi e se chamava Sua vida me pertence ${ }^{4}$, exibida ao vivo. Os 15 capítulos iam ao ar às terças e quintas-feiras. A primeira telenovela diária foi ao ar em 1963, intitulada 2-5499 Ocupado $^{5}$, uma produção da TV Excelsior.

Mas foi nas décadas de 1970 e 1980 que as telenovelas se consolidaram principalmente em parcerias com poetas. Rebouças (2009) enfatiza algumas características da nova estética e conteúdo das telenovelas

Nas décadas de 1970 e 1980, consolidou-se a fórmula brasileira: colaboração de grandes novelistas e poetas, maior aproximação da época contemporânea, desmistificação do passado, linguagem coloquial e regional, apresentação de fatos reais, influência do teatro de vanguarda, aparecimento do anti-herói mentiroso, corrupto e de figuras femininas originais, finais abertos, elaboração sutil da comédia e da tragédia (REBOUÇAS, 2009, p. 1).

Neste contexto, a obra do autor Jorge Amado ${ }^{6}$ é marcada por várias adaptações televisivas, que visibilizaram questões de natureza sociológica: Gabriela (1975), Terras do sem fim (1981), Tenda dos milagres (1985), Tieta (1989), Capitães de areia (1989), Tereza Batista (1992), Tocaia Grande (1995), Dona Flor e seus dois maridos (1998), Porto dos milagres (2001), Pastores da noite (2002) e Gabriela (2012), remake da primeira versão exibida em 1975, em homenagem ao centenário do escritor.

Jorge Amado reverencia em suas obras a Bahia e o Nordeste brasileiros, trazendo cores e sentimentos da região, disseminando personagens fortes e sedutoras. Araújo (2003) explica que a essência da obra amadiana é o sentido de "liberdade e revolução, ideia e símbolo, romantismo e realismo, assim se pauta a narrativa amadiana, painel mural inflado de brasilidades" (ARAÚJO, 2003, p. 154). Dessa forma, negros, mulheres,

\footnotetext{
${ }^{4}$ Escrita por Walter Foster, era também dirigida e estrelada por ele, que dividia a cena com as atrizes Vida Alves e Lia de Aguiar. A trama foi contada em apenas 15 capítulos, de 20 minutos de duração, que eram exibidos ao vivo e duas vezes por semana, às terças e quintas, às 20 horas. Havia apenas dois cenários: um quarto e o jardim de uma praça.

${ }^{5}$ Foi exibida de 22 de julho a setembro de 1963, pela TV Excelsior, numa adaptação de Dulce Santucci para o original do argentino Alberto Migré, com direção de Tito Di Miglio. Foram produzidos 42 capítulos, que duravam cerca de 20 minutos e geralmente tinham apenas duas cenas. Doze personagens integravam a trama.

${ }^{6}$ Jorge Amado nasceu dia 10 de agosto de 1912, na fazenda Auricídia, no distrito de Ferradas, município de Itabuna, sul do Estado da Bahia. Filho do fazendeiro de cacau João Amado de Faria e de Eulália Leal Amado.
} 


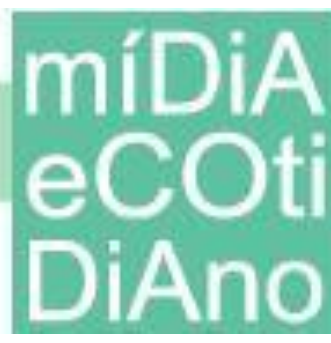

mulatos, nordestinos, pobres, operários, etc., em condições de luta contra a subalternidade, notabilizam as injustiças sociais apontando caminhos vanguardistas acerca da representatividade dos grupos discriminados pela elite branca e excludente.

\section{Ninguém nasce mulher, torna-se mulher}

O machismo arraigado em nossa sociedade não está preparado para lidar com o protagonismo da mulher e há um empenho não em valorizá-la, mas em silenciá-la, produzindo situações de subalternidade. Apesar do avanço ao longo dos anos, verificado na inserção em ambientes públicos até então destinado a homens, temos ainda uma longa trajetória a ser percorrida pelas mulheres na equiparação aos espaços e direitos. Por isso, Butler (2003) afirma: "não basta inquirir como as mulheres podem se fazer representar mais plenamente na linguagem e na política. A crítica feminista também deve compreender como a categoria das "mulheres", o sujeito do feminismo, é produzida e reprimida pelas mesmas" (BUTLER, 2003, p. 19).

A célebre frase de Simone de Beauvoir, que remete ao fato de nos tornarmos alguém, já lembrada neste texto surge para reiterar que gênero é uma construção social, sempre em processo. Por muito tempo, o gênero entendido como "biológico" - ou seja, definido pelo sexo - explicava como o homem ou a mulher se colocariam e se posicionariam no mundo. Antes mesmo do nascimento, alguns detalhes já eram definidos, como, por exemplo, a cor do enxoval da criança: se fosse homem seria azul; se fosse mulher, rosa. Após o nascimento, tais questões iriam se intensificar, permitindo que, na sociedade e na cultura, o homem assumisse o papel de macho provedor e a mulher de fêmea reprodutora.

Porém, é importante esclarecer que sexo biológico é diferente de gênero. A criança nasce biologicamente com um conjunto de órgãos que a definem sexualmente como homem ou como mulher. Entretanto, gênero, na atualidade, é definido culturalmente. Butler (1990) já afirmava a mobilidade do conceito a partir de papéis sociais:

[...] por mais que o sexo pareça intratável em termos biológicos, o gênero é culturalmente construído: consequentemente, não é nem o 
resultado casual do sexo, nem tampouco tão aparentemente fixo quanto o sexo. Assim, a unidade do sujeito já é potencialmente contestada pela distinção que abre espaço ao gênero como interpretação múltipla do sexo (BUTLER, 1990, p. 24).

Alves e Pitanguy (1985) explicam que o conceito se vincula a uma construção sociocultural, que atribui papéis diferentes para homens e mulheres dentro da sociedade, de acordo com os costumes de cada lugar, da experiência cotidiana das pessoas, bem como da maneira como se organiza a vida familiar e política. Esses papéis são construídos culturalmente, variando conforme o tempo e o lugar. Já Beauvior (1967) contextualiza as situações impostas às meninas na infância para ilustrar o ciclo dos papéis de gênero atribuídos a uma mulher e um homem:

Tratam-na como uma boneca viva e recusam-lhe a liberdade; fecha-se assim um círculo vicioso, pois quanto menos exercer sua liberdade para compreender, apreender e descobrir o mundo que a cerca, menos encontrará nele recursos, menos ousará afirmar-se como sujeito; se a encorajassem a isso, ela poderia manifestar a mesma exuberância viva, a mesma curiosidade, o mesmo espírito de iniciativa, a mesma ousadia que um menino (BEAUVIOR, 1967, p. 22).

Percebemos, pois, que o gênero feminino por muito tempo não foi enxergado como importante na sociedade. Para Rago (2012), os "estudos da mulher" mostravam que essa não deveria ser pensada como uma essência biológica pré-determinada, "mas como uma identidade construída social e culturalmente no jogo das relações sociais e sexuais, pelas práticas disciplinadoras e pelos discursos/saberes instituintes" (RAGO, 2012, p. 29).

A personagem Gabriela aparece na cena literária brasileira como uma relevante representação do feminino. Tanto que Jorge Amado confessou em entrevista que "queria criar uma mulher que fosse símbolo da mulher brasileira". A intenção levou o escritor a criar uma personagem negra, nordestina, retirante da seca que assolava o sertão baiano, para retratar o que acontecia na década de cinquenta no nordeste do país. Assim como Gabriela, Tieta é outra personagem relevante que supera os estigmas e subverte a ordem estabelecida. Após ser humilhada e expulsa da cidade, esperava-se, talvez, um enredo protagonizado por uma mulher enfraquecida apta a desistir sem se reerguer.

Porém, Jorge Amado nos apresenta uma heroína que subverte as expectativas e rompe com o sistema patriarcal. Na sua trajetória, mostra-se uma mulher que vive 


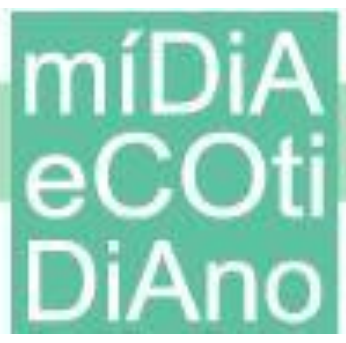

segundo suas próprias regras, exercendo sua liberdade e tornando-se inspiradora para outras, ensinando-lhes a não se submeter a casamentos arranjados e nem a receber ordens dos homens. Ao contrário, Tieta frequenta os mesmos lugares masculinos de poder e ainda se torna uma espécie de "santa" no Agreste por incentivar o empoderamento feminino.

Apesar de a novela ter sido exibida na década de 1980, Tieta traz para a cidade pacata e interiorana de Santana do Agreste, um olhar de coragem e de progresso que contagia o Brasil, defendendo a ideia de que a mulher pode exercer seu protagonismo independentemente de espacialidades geográficas. Na segunda fase da trama, quando volta de São Paulo 25 anos depois de sua expulsão, aparece num conjunto vermelho de couro decotado e colado ao corpo; com cerca de quarenta anos, bonita, sensual, dona de sua sexualidade e de seu dinheiro, signos de uma transformação feminina que choca a sociedade conservadora. Ela diz, com seu comportamento, à sociedade brasileira e principalmente às mulheres, que é possível viver em liberdade por seus próprios méritos, conquistando seu lugar de fala numa sociedade preconceituosa.

Dessa forma, o lugar de fala se torna um conceito essencial para a discussão do empoderamento, sendo explicado por Ribeiro (2016) como um rompimento de uma norma vigente que legitima o direito de uma só voz, cujos padrões recorrentes são a branquitude e a masculinidade. Com a ruptura desses padrões, protagonistas mulatas como Gabriela e Tieta desafiam as normas do masculino e os conceitos eurocêntricos provocando identificações entre uma audiência permeada, em sua maioria, por uma população mestiça condizente às origens de formação do povo brasileiro.

A partir da quebra de conceitos, a única voz instituída como dominante, equivalente à voz do masculino, abre espaço para a diversidade e cria um novo espaço social onde múltiplas vozes podem se fazer ouvir. Além do forte sexismo que sempre objetificou a mulher negra, o racismo histórico também impediu a sua dignidade já que não foi vista em igualdade de condições à mulher branca. Verificamos, através da ficção amadiana, o quanto a mulher negra foi relegada à erotização em desprezo as suas reais potencialidades como ser humano, antes que pudesse alcançar a realização de seus desejos. Tieta foi expulsa da cidade por ter um comportamento não sujeito às amarras sociais da sexualidade. Já na trama de Gabriela, percebemos o quanto a cor da 


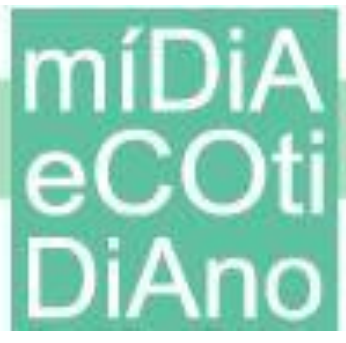

protagonista é vista pelo masculino como veículo de desejo e apropriação. Tais estereótipos constroem um retrato de uma sociedade, na qual a cor negra é tratada como "pecado" desde a época escravocrata, marcada por senhores da "casa grande" que, em nome da posse de outros seres humanos, humilhavam e estupravam as escravas como se fossem objetos de suas vontades.

Mas a violência não é somente criação ficcional. O Atlas da Violência 2018 do Instituto de Pesquisas Econômicas Aplicada (IPEA) e do Fórum Brasileiro de Segurança Pública indica que, no Brasil, morrem 71\% mais mulheres negras do que brancas, e que nos últimos dez anos, os números de assassinato caíram $8 \%$ entre as mulheres brancas e aumentaram 15,4\% entre as negras. Estes dados confirmam a importância do estudo sobre as mulheres negras, no que diz respeito ao feminino e às lutas raciais. Ao discutirem essa realidade, as telenovelas produzem uma reflexão sobre o pensamento patriarcal denunciando essa problemática.

De acordo com Ferreira (2018), os estereótipos de subserviência, pobreza, sofrimento (a "Tia Anastácia", as escravas, empregadas, babás e trabalhadoras braçais, "sem autoridade") e a desigualdade espacial (circunscritas às favelas e comunidades carentes) caracterizam as mulheres negras na ficção e nas práticas cotidianas, ou seja, no mercado de trabalho, no contexto familiar, nos relacionamentos afetivos e em diversos outros espaços de sociabilidade (FERREIRA, 2018, p. 396-397).

Nesse sentido, o debate de gênero engloba a violência contra as mulheres, estendendo-se à violência psicológica, sexual, física, agressões verbais, assédio sexual, discriminação, prostituição forçada, incluindo tráfico de pessoas, mutilação, tortura e feminicídio (LOURO, 2010b). Todos esses aspectos estão presentes em Gabriela, uma mulher cuja autenticidade rompe a ordem social e abala o falso moralismo da cultura vigente, "deixando evidente aos poucos as marcas dos que vêm de baixo, quando ela ascende de cozinheira à esposa do patrão, de amante à suposta mulher de sociedade" (COUTINHO, 2011, p. 199).

Aliás, vale sublinhar que a utilização da palavra "mulata" em ambas as tramas ocorre para se referir à mulher negra e, assim, erotizar, semanticamente, os seus corpos. Ferreira (2018) destaca que "a referência constante à "mulata", (...) revela a naturalização de uma sexualidade exacerbada atribuída à mulher negra" (FERREIRA, 2018). O racismo 
e o sexismo se transformam em um instrumento de violência contra essa mulher. Exatamente por essas questões, e pelo poder de influência da mídia televisiva como formadora de novas representações, é importante se pensar o protagonismo das mulheres negras no âmbito das produções para se discutir os estereótipos nelas difundidos. Gabriela e Tieta, negras e nordestinas, embora sejam retratadas com sensualidade, permitem a discussão do paradigma da exploração sexista ao se posicionarem contra os valores impostos pela sociedade da época.

\section{Assim são Gabriela e Tieta: representações de empoderamento e liberdade}

As descrições das tramas foram originalmente realizadas para o projeto de pesquisa citado. A categoria representação diz respeito a "uma forma de conhecimento socialmente elaborada e partilhada, tendo um objetivo prático e concorrendo à construção de uma realidade comum a um conjunto social" (JODELET, 1994, p. 36). A partir do conceito de representação pudemos construir uma análise sobre as telenovelas, partindo do pressuposto de que as personagens estudadas podem inspirar noções de liberdade a outras mulheres escravizadas pelas convenções sociais.

Gabriela foi exibida em 2012, às 23 horas, numa adaptação de Walcyr Carrasco e direção de Mauro Mendonça Filho, com 77 capítulos. Tieta, com exibição no horário nobre, registrou 196 capítulos, indo ao ar pela primeira vez entre os anos de 1989 e 1990, adaptada por Aguinaldo Silva (sua reprise ocorreu em $1^{\circ}$ de maio de 2017 no canal pago VIVA do grupo Globosat).

Gabriela (Juliana Paes) é uma retirante nordestina que começa uma luta por afirmação pessoal ignorando as regras sociais da cidade interiorana e a formalidade do casamento. As personagens secundárias dessa ficção são exemplos importantes para se refletir sobre a violência contra a mulher e o feminicídio. Sinhazinha (Maitê Proença) é símbolo dessa conjuntura porque, devota de São Sebastião, foi assassinada pelo marido, Coronel Jesuíno Mendonça (José Wilker), após o flagrante de adultério com o dentista Osmundo Pimentel (Erik Marmo), ironicamente parecido com a imagem do seu santo de devoção. Vemos aí o protótipo da religiosidade como símbolo de virtude da personagem, constituindo uma qualidade valorizada pelos maridos e as famílias socialmente abastadas. A abordagem da traição revela não apenas o adultério no casamento como algo a ser 


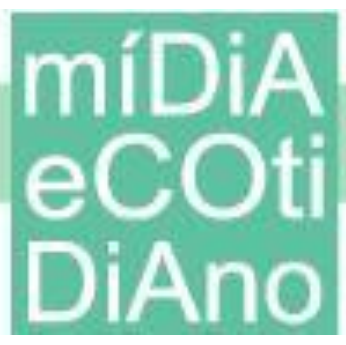

condenado coletivamente, mas revela também a ruptura com uma moral religiosa que incentivava a mulher a ser tratada como propriedade. Como uma esposa devotada e respeitável, era esperada de Sinhazinha uma vida de dedicação à Igreja sem direito à felicidade conjugal. Ao se apaixonar pelo dentista, ela rompe com o código moral da sociedade.

Malvina (Vanessa Giácomo) também é uma personagem secundária relevante, pois é uma jovem que não se submete a um casamento arranjado, conforme as convenções vigentes. Na tentativa de moldar seu comportamento, o pai da jovem, Coronel Melk Tavares (Chico Diaz), a proíbe de estudar, valendo-se do seguinte argumento: "mulher que se mete a doutora é mulher descarada, que quer se perder" (GABRIELA, 2012). Posteriormente, ela questiona os padrões e os telespectadores observam o envolvimento da moça com um homem casado e sua posterior fuga para São Paulo, atitudes que chocam os valores familiares e conservadores da época.

Zarolha (Leona Cavalli) é uma prostituta do Bataclã (administrado por Maria Machadão, vivida por Ivete Sangalo), que acolhe os homens da cidade num ambiente festivo e erótico, apresentando atrações como shows de música e dança e jogos de azar. Apesar dos homens frequentadores do Bataclã entenderem que podem possuir qualquer mulher daquele lugar, desde que paguem por ela, Zarolha não se sujeita a essas condições por estar apaixonada. É, por essa recusa, advertida por Maria Machadão, que diz à moça que é necessário se deitar com quem paga mais para poder no futuro viver bem.

Já a protagonista Gabriela encanta o coração do turco Nacib (vivido por Humberto Martins) e os dois se envolvem afetivamente numa relação que é reprovada pela sociedade. Com um espírito espontâneo, que se revela nos modos como transmite sexualidade e erotismo, Gabriela exerce, primeiro, a função de cozinheira, chegando à vida do patrão Nacib em condição subalterna. Depois, transforma-se em sua amante e, posteriormente, conquista a posição social de esposa, papel que contraria a sua liberdade. Tolhida pela vigilância moral da sociedade, a personagem transgride a ética e as regras que lhe sufocam traindo o marido. Com essa conduta indisciplinada, desafia a instituição do casamento com suas restrições, e ainda afronta a sociedade conservadora ao interrogar “as adequações e obrigações” atribuídas às mulheres “decentes". 
Tieta, a personagem-título da outra trama (vivida nas duas fases respectivamente por Cláudia Ohana/Betty Faria), é pastora de cabras na adolescência, chocando a família e a cidade interiorana por não reprimir seus impulsos sexuais. Esse é o motivo que a fez ser expulsa de casa, aos 16 anos, pelo pai conservador Zé Esteves (Sebastião Vasconcelos), acusada de libertinagem. Após uma violenta surra de cajado em praça pública, a jovem foge para São Paulo prometendo voltar, em suas palavras, "não para implorar clemência, mas para se vingar". Torna-se prostituta para sobreviver e logo depois dona de um bordel luxuoso na capital, em virtude das relações de favores construídas com políticos influentes.

Sua volta coincide com a celebração de uma missa em intenção de sua morte. Tieta interrompe a celebração religiosa, mostrando-se mais viva e poderosa do que nunca, anunciando que veio rever sua família. A cidade é surpreendida com essa aparição e passa a especular tanto as razões do seu sumiço quanto as do seu retorno. A protagonista conta a todos estar viúva do fictício Comendador Felipe Cantarelli, de quem adotou o sobrenome, para não levantar suspeitas sobre a real fonte de sua fortuna. Apresenta, então, Leonora (Lídia Brondi), como enteada, uma moça que aparenta recato, mas que, na verdade, é uma das meninas que acolheu no bordel e por quem Tieta nutre um sentimento materno, por reconhecer na jovem a mesma garota sonhadora que foi na sua juventude.

Após os primeiros momentos do reencontro, a protagonista logo se decepciona ao descobrir que a sociedade, que hoje a bajula e venera, continua mesquinha e preconceituosa, a mesma que a hostilizou no passado. A propósito da trama, Belline (2008) explica que o mundo do Agreste, aparentemente simples e pacífico, revela-se, para a protagonista, mais difícil de lidar do que o universo do meretrício. Lá, os sentimentos, como os corpos, estão expostos, sem simulações. Na cidade natal, onde Tieta busca reencontrar a sua identidade, sobram engano e falsidade; ninguém diz tudo o que pensa nem demonstra seus sentimentos; todos encobrem algo por interesse, medo ou pobreza. Nesse sentido, a autora descreve que a narrativa de Jorge Amado chama a atenção para a dualidade entre aparência e realidade por situar o espaço do bordel, embora mais degradado aos olhos da sociedade, como mais "honesto" que a cidade pequena, apenas exteriormente "decente". 
Outra personagem significativa para o estudo das implicações de gênero, nessa trama, é Tonha (Yoná Magalhães), segunda mulher de Zé Esteves, bem mais jovem que o marido, e que vive grande transformação idealizada por Tieta. Ela também sofre a violência do cajado de Zé Esteves, artefato que o velho pastor de cabras utiliza para impor sua "autoridade" na família e que permanece um grande símbolo de sofrimento para Tieta. Mãe de Elisa (Tássia Camargo), Tonha tenta controlar os impulsos da filha sonhadora, que idealiza romances eróticos com atores de fotonovelas e artistas da TV - que nem chegam a Santana do Agreste - e de cujas vidas acompanha as fofocas num programa de rádio.

Imaculada (Luciana Braga) também favorece importantes leituras das relações de gênero. Uma jovem destemida que foi vendida ao Coronel Artur da Tapitanga pelos próprios pais, mas que não se submete ao seu assédio sexual. Depois de tentativas de fugas frustradas, a jovem será resgatada na Casa da Luz Vermelha, espaço de prostituição de Santana do Agreste, onde também se rebela contra a servidão. Essa personagem vai viver um amor romântico com Ricardo (Cássio Gabus), após a relação tumultuada do sobrinho com Tieta, numa paixão proibida.

Em relação à Gabriela, destacamos o capítulo 02, que começa com Nacib "contratando" a moça para ser sua cozinheira no mercado de retirantes. A caminho da casa de Nacib, Gabriela, que estava suja de lama e poeira, encontra uma fonte no centro da cidade e corre até ela para tomar um banho sem perceber a reação que causa nos observadores da cena. Os homens que passavam a olham e cobiçam com desejo, enquanto a protagonista, dada a sua espontaneidade, não se dá conta do efeito provocado.

\section{Figura 1 - Gabriela toma banho em praça pública}

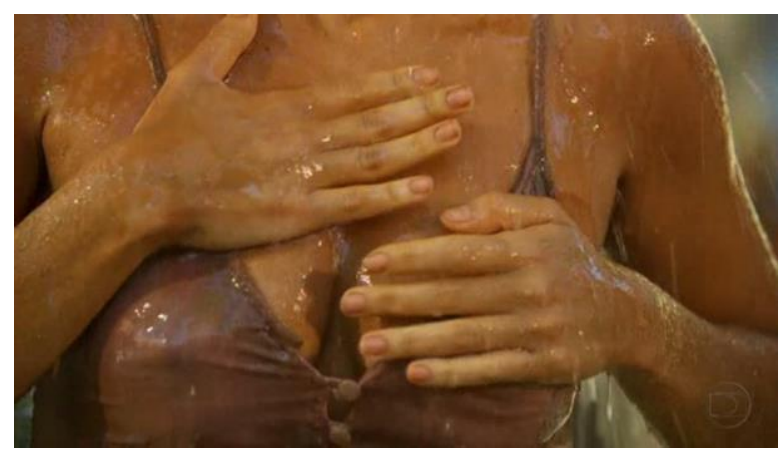

Fonte: print screen da telenovela Gabriela (2012). 
A objetificação e sexualização femininas também são vivenciadas pela protagonista quando caminha na pacata Ilhéus em direção ao Bar do Vesúvio (que pertence a Nacib) para levar as refeições do patrão. Durante o seu percurso, a moça chama a atenção dos homens que param e fazem insinuações ao vê-la passar.

\section{Figura 2 - Gabriela em direção ao Bar do Vesúvio}

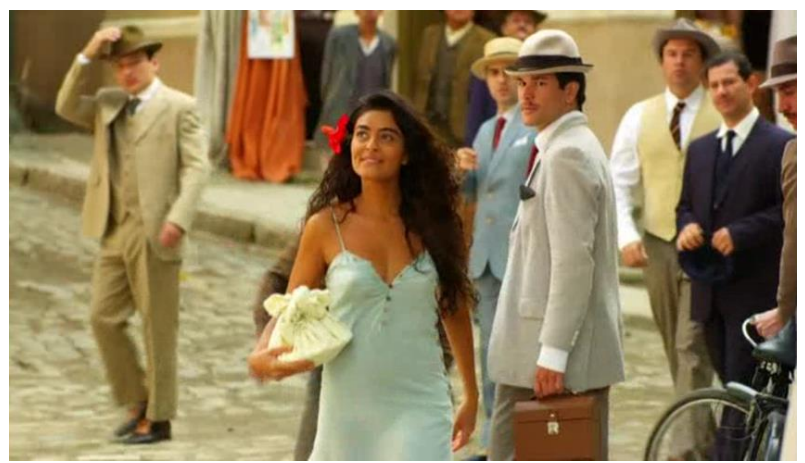

Fonte: print screen da telenovela Gabriela (2012).

Ao chegar no local, alguns homens se levantam e lhe dirigem palavras gentis, admirados com a sua presença, enquanto ela abaixa a cabeça. Notamos, nessa passagem, o discurso machista sobre a mulher e sua objetificação:

- Manoel das Onças (Mauro Mendonça): - Que pitel essa Gabriela, hem? [Olhando para Coronel Ribeirinho (Harildo Deda), em busca de confirmação, que, por sua vez, passa a língua nos lábios em sinal de "apetite"!]. A moça, então, se dirige ao balcão do bar onde seu patrão lhe aguardava: - Gabriela: - Eu trouxe seu almoço, Seu Nacib. - Nacib: - Ah sim, claro, o almoço, venha me servir aqui nos fundos (Tenta retirar a moça do local para evitar mais olhares e comentários). Nas mesas, os homens continuam os comentários: - Nhô Galo (Edmilson Barros): - Ela trouxe o almoço, mas será que é cozinheira mesmo? Dr. Ezequiel: - Sei não... Olhe, é nela que eu queria dar uma garfada! - Tonico (Marcelo Serrado): Nacib tá me saindo muito bem, delícia de mulher! (GABRIELA, 2012, cap. 2, decupagem elaborada pelo autor).

Os fragmentos apontam o que Hanciau (2002) nos lembra, de que a paixão “erótica e exótica”, despertada por Gabriela, também sugere uma perspectiva canibalesca sutil para a narrativa, criando as ideias de "mulher-refeição" e "mulher-presa" no contexto da trama, transferindo para a protagonista uma imagem estimulante aos olhos dos homens, que disputavam entre si quem haveria de "caçá-la, comê-la, devorá-la" num 


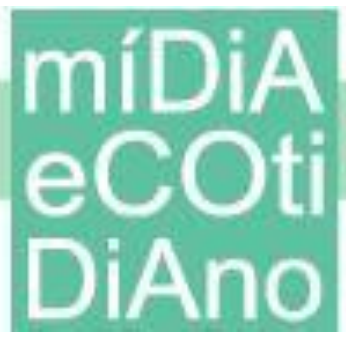

esquema representativo e simbólico de relações inter-raciais objetificadas. Assim, metaforicamente, os sentidos do olfato, da visão e do paladar são mobilizados por esses signos para sugerir conotações eróticas e sexuais sobre a protagonista, que não é vista como mulher nessas situações, mas como um "objeto de captura".

Falemos, neste momento, da beata Sinhazinha, que aparece, no capítulo 15, na cama do dentista Osmundo Falcão, seu amante, após uma das noites infelizes em que passou na companhia do marido, o coronel Jesuíno. Como mencionado, a mulher se dedica à Igreja, junto com as demais damas da cidade, por não sentir amor e felicidade no matrimônio, ao qual somente se submete por convenção social. Percebemos, portanto, que o recurso da fé aparece para ela como fuga da situação de violência simbólica e física a que é submetida, buscando esquecimento no envolvimento diário das tarefas religiosas.

Uma noite, após negar se deitar com o coronel, ele continua insistindo, dizendo que "mulher quando casa com o marido, ela faz o que o marido quer" (GABRIELA, 2012) e a agride. Eis o diálogo que culminou nessa violência:

- Jesuíno: - Por que não jantou comigo, dona Sinhazinha? Sinhazinha: - Eu estou indisposta (Repete para disfarçar o sentimento de repulsa)! - Jesuíno: - Deite, que eu vou lhe usar! - Sinhazinha: O senhor não ouviu que eu estou indisposta? (Queixa-se com tristeza) Jesuíno: - Mulher minha não fica indisposta! Quando eu quero, já sabe, deite, hoje eu tô com vontade! (Grita) - Sinhazinha: - Mas eu não estou com vontade! (Insiste) - Jesuíno: - Não me importa, deite de uma vez! - Sinhazinha: - Hoje não, eu me recuso! (Entre lágrimas) - Jesuíno: - Se recusa? Se recusa pro teu marido? - Sinhazinha: Minha cabeça dói [Coloca a mão na cabeça em sinal de desespero!]. Jesuíno: - Eu não estou interessado em sua cabeça! Deite! (Continua gritando) - Sinhazinha: — Eu peço, hoje não, hoje não, hoje eu não posso! - Jesuíno: - Se não for por bem, vai ser por mal! - Sinhazinha: - Marido, eu peço que me compreenda, é só dessa vez, hoje eu não posso! (Implora) - Jesuíno: - Ninguém me diz não "nunca", muito menos minha mulher! [Nesse momento, ele a joga na cama e Sinhazinha se desvia, correndo pelo quarto]. - Jesuíno: - Como se atreve? Eu lhe dou tudo, casa, comida e roupa boa! Você come da minha mão! - Sinhazinha: - Eu não sou mendigo, coronel Jesuíno, o meu pai tinha fazenda de cacau... (Ela alega) - Jesuíno: - E o que foi feito dessa fazenda? Ficou pro teu irmão. Você veio pra mim com uma miséria de dote, eu te aceitei por conta de tua beleza, eu fui é tolo! - Sinhazinha: - Mas fala comigo como se eu fosse um gado que se compra! - Jesuíno: - É quase isso. Mulher quando casa com o marido, ela faz o que o marido quer! E o que eu quero agora é que você cale a boca e abra as 
pernas! - Sinhazinha: - Eu não sou bicho! Eu sou gente, eu sou gente! [Coronel Jesuíno bate na mulher] - Jesuíno: - Vai me obedecer agora, ninguém diz não pra mim, nunca! [Sinhazinha corre outra vez e ele a segura e a coloca contra a parede] - Jesuíno: - Ainda se nega? [Sinhazinha balança a cabeça, afirmando]. - Jesuíno: - Melhor, gosto mais assim... Se recusa a deitar, melhor! Eu vou te usar aqui mesmo em pé, diz que é gente né? Eu vou te usar feito bicho! [Nesse momento ele a segura contra a parede e a força a ter relações sexuais] (GABRIELA, 2012, cap. 15, decupagem elaborada pelo autor).

\section{Figura 3 - Coronel Jesuíno bate em Sinhazinha}

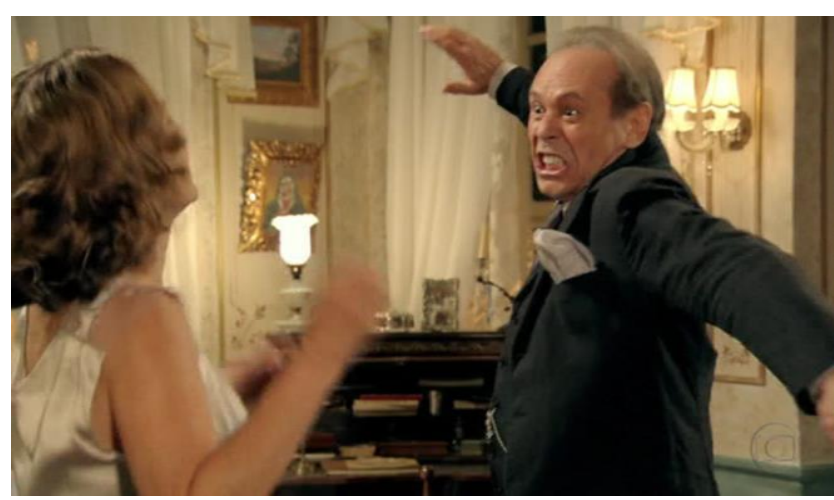

Fonte: print screen da telenovela Gabriela (2012).

Gilberto Freyre (2002) já destacava que "é característico do regime patriarcal, o homem fazer da mulher uma criatura tão diferente dele quanto possível. Ele, o sexo forte, ela o fraco; ele o sexo nobre, ela o belo" (FREYRE, 2002, p. 805). Cria-se, nesse sentido, a objetificação feminina. Nesse contexto, a mulher seria vista pelo marido como "uma coisa" para seu uso e prazer, sendo obrigada a satisfazer as vontades do homem na hora em que ele desejar. Isso explica a violência simbólica, quando o coronel Jesuíno a tratava como um "animal adestrado", pois a esposa era obrigada a satisfazer as vontades dele, sem prazer algum. A violência física acontece como forma de imposição do coronel e de expressão de sua autoridade, ao afirmar que “ninguém diz ‘não' pra mim” (GABRIELA, 2012), batendo na mulher para reafirmar a sua posse, que a tinha comprado e que, por isso, em troca ela lhe devia obediência.

Passemos, neste momento, à discussão de gênero em Tieta, a segunda telenovela estudada. Tieta, acusada de libertinagem desde muito nova pela sociedade de Santana do Agreste, não controla seus impulsos sexuais e seus desejos. O seu pai, Zé Esteves, a violenta e a expulsa da cidade após descobrir que ela se envolvia com um homem mais velho. 
Após um processo de autoconhecimento e afirmação de si, a jovem, agora uma mulher independente e poderosa, retorna após 25 anos à Santana do Agreste, disposta a mudar não somente o cenário local, como a realidade de mulheres presas e oprimidas pelos companheiros. Uma personagem periférica torna-se oportuna no contexto da trama. Trata-se de Tonha.

No capítulo 16, Tonha, ao sair da pensão de dona Milu (Miriam de Souza Pires), juntamente com a filha Elisa, Timóteo e Ricardo, Zé Esteves - com o seu inseparável cajado, símbolo da opressão masculina - os encontra a caminho da Igreja. Observa com raiva a roupa da esposa e logo a proíbe de ir às festividades religiosas. Elisa tenta intervir a favor da mãe e Tonha tenta resistir à ordem do marido, argumentando que a blusa era um presente de Tieta, tentando convencê-lo a “autorizar". Mas ele rasga a peça no corpo da mulher:

- Tonha: - Zé Esteves... (Chocada com a reação do marido) - Zé: Sua desgramada, tu tá pensando que vai onde com essa roupa, vestida desse jeito? Na Casa da Luz Vermelha? (Em referência ao cabaré da cidade) - Tonha: - É a roupa que Tieta me deu, como hoje tem uma festa, eu pensei que... - Zé: - Pensou? E desde quando eu lhe dei o direito de pensar? Me diga! [Grita, e Elisa, então, vira-se para o pai para defender a mãe] - Elisa: - Não, pai, deixa de ser exagerado, só porque mainha se arrumou, se vestiu direito, se ajeitou toda... - Zé: - Eu quero é que ela fique mesmo é esfarrapada, é assim que eu gosto! Num tá vendo que eu não vou deixar minha mulher se dar a um desfrute desse? E oferecida na família, dona Eliza, basta você! Vá pra casa, vá vestir uma roupa decente! - Tonha: - Vou não, tô me sentindo bem assim, é assim que eu vou ficar! - Zé: - Não vai não, o quê? Mas num vai mesmo! [Neste momento, rasga a roupa da mulher no meio da rua, que fica despida e chora desesperadamente na frente de todos!] (TIETA, 1989-1990, cap. 16, decupagem elaborada pelo autor)

\section{Figura 4 - Zé Esteves rasga a roupa de Tonha}

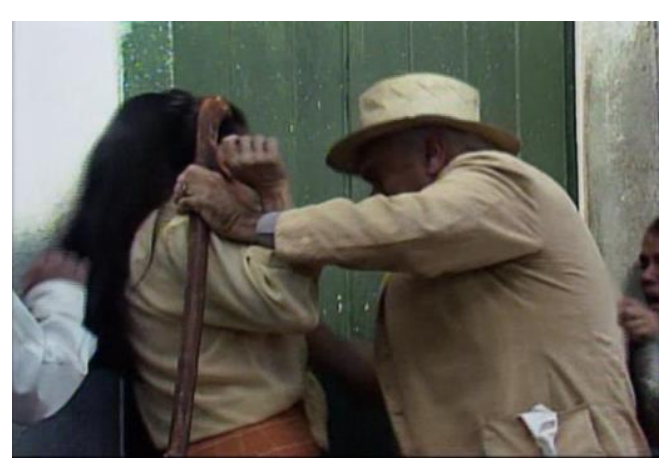

Fonte: print screen da telenovela Tieta (1989-1990). 
A violência doméstica legitimada pelo matrimônio é reconhecida pela sociedade da época, que percebe os atos abusivos do marido como algo natural para manter a solidez do casamento. Enquanto Zé Esteves rasga a roupa da esposa, num ato covarde e machista, ninguém fala nada, as pessoas apenas olham, até se entristecem, mas não a defendem da violência. Tieta surge, após ouvir os gritos de Tonha, e intervém em favor da amiga e madrasta. Já Tonha, muito assustada, ainda pede a Tieta para não gritar com o pai. Tieta, então, afirma que vai dar outra roupa a ela e que "isso não iria ficar assim" (TIETA, 19891990). Embora seja filha de Zé Esteves, conhecido como homem rude, Tieta o enfrenta e não se curva às suas crueldades, reafirmando a representação de heroína que se coloca disposta e corajosa para defender o que julga ser justo.

Durante a telenovela Tieta, algumas personagens periféricas ganham protagonismo ao se rebelarem contra o sistema patriarcal e machista, desfazendo os nós que as mantinham confinadas ao lar. O processo de transformação incentivado por Tieta é chamado de "empoderamento", uma vez que questiona as ideologias e as relações de poder que oprimem as pessoas, conforme esclarece Batliwala (1994):

o termo empoderamento se refere a uma gama de atividades, da assertividade individual até a resistência, protesto e mobilização coletivas, que questionam as bases das relações de poder. No caso de indivíduos e grupos cujo acesso aos recursos e poder são determinados por classe, casta, etnicidade e gênero, o empoderamento começa quando eles não apenas reconhecem as forças sistêmicas que os oprimem, como também atuam no sentido de mudar as relações de poder existentes. Portanto, o empoderamento é um processo dirigido para a transformação da natureza e direção das forças sistêmicas que marginalizam as mulheres e outros setores excluídos em determinados contextos (BATLIWALA, 1994, p. 130).

Carol (Luiza Tomé), uma das personagems emblemáticas e que conquista protagonismo durante a trama, ilustra bem essa problemática. A moça bonita $\mathrm{e}$ dependente do amante consegue, com a ajuda de Tieta, se libertar dos adjetivos pejorativos "teúda" e "manteúda"7 em relação a Modesto Pires (Armando Bógus), um poderoso comerciante local que a conservava como um troféu de masculinidade.

\footnotetext{
${ }^{7}$ Definição de pessoas que são sustentadas financeiramente por um indivíduo na forma de “amantes”.
} 
No capítulo 76, Tieta conversa com Carol sobre um cadeado com a corrente quebrada, numa analogia à vida da jovem presa a essa condição humilhante:

- Tieta: - Tu lembra daquele presente que eu te mandei? - Carol: Aquele cadeadinho com a corrente quebrada? É claro! - Tieta: - Tu entendeu o que aquilo significava? - Carol: - Bem, se a senhora... Tieta: - Senhora não, criatura, me chame de você. - Carol: - Tá bom, se você quer assim... ocê num sabe da missa a metade. $O$ fato é que depois que você me mandou aquele cadeadinho, aos pouquinhos minha vida vem mudando... - Tieta: - Pra melhor ou pra pior? - Carol: Vixe Maria, acho que pra muito melhor! - Tieta: - Então o presente fez o efeito que eu queria, mesmo que tu não tenha entendido o porquê de eu ter feito aquilo. - Carol: - É, não entendi muito bem direitinho, não. - Tieta: - $\hat{O}$, criatura, eu tava lhe mandando quebrar a corrente que lhe prendia, soltar o cadeado! Essa história de ser teúda e manteúda, de depender de homem pra viver, isso já era, Carol! Tu tinha mais é que ser dona do teu próprio nariz.- Carol: - Oxente, pois eu acho que tô conseguindo, quebrei o cadeado, arrebentei aquela corrente e já não sou mais a mesma. Mudei! (TIETA, 1989-1990, cap. 76, decupagem elaborada pelo autor).

\section{Figura 5 - Tieta e Carol conversam sobre liberdade}

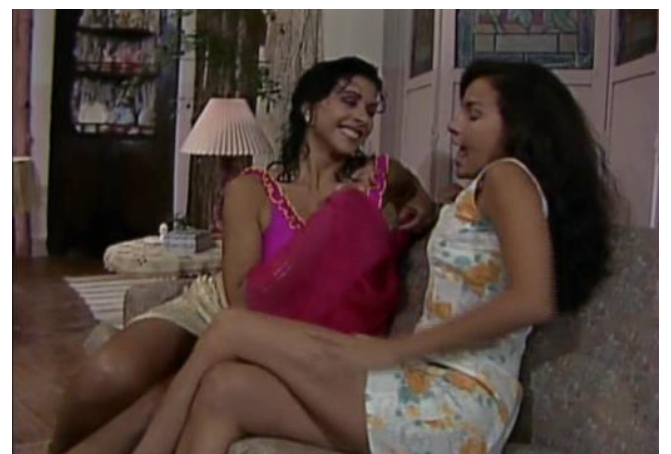

Fonte: print screen da telenovela Tieta (1989-1990).

Ao propor às mulheres a percepção do empoderamento como algo possível a todas, a telenovela Tieta contesta o sistema patriarcal aludindo às liberdades individuais para além dos estereótipos de gênero. Para Freire e Shor (1986),

a libertação é um ato social (...), [portanto], se você não é capaz de usar sua liberdade recente para ajudar os outros a se libertarem através da transformação global da sociedade, então você só está exercitando uma atitude individualista no sentido do empowerment ${ }^{8}$ (FREIRE; SHOR, 1986, p. 71).

\footnotetext{
${ }^{8} \mathrm{O}$ termo é muito utilizado no universo organizacional para designar "descentralização da liderança" cujo modelo de gestão é mais aberto e participativo.
} 


\section{míDiA

Considerações finais

O texto buscou demonstrar que, ao longo das décadas, as telenovelas exercem papéis de informação e debate de questões sociais que transcendem o território da ficção apelando para a reflexão e disseminando posturas que questionam os estereótipos. Apesar de terem surgido como meios para entreter e confinar as mulheres dentro do espaço privado, as telenovelas se apropriam desse aspecto para apontar caminhos de liberdade a essas mulheres, juntamente com o movimento feminista que eclodiu no Brasil.

A análise revelou que tanto Tieta, quanto Gabriela, são tramas vanguardistas, que problematizam e denunciam as violências sofridas por mulheres no nordeste brasileiro. As instâncias formadoras da sociedade (Família, Escola e Igreja) distribuem papéis desiguais a homens e mulheres, refletindo o sistema patriarcal. Apesar das conquistas femininas do direito ao voto, da liberdade sexual e da inserção no mercado de trabalho, que incentivaram as mulheres a questionar a submissão, a ficção audiovisual exerce seu papel de difundir as questões de uma determinada época, como verificamos através das protagonistas e personagens das tramas estudadas, que ainda ilustram preconceitos e formas de violência contra a mulher que precisam ser combatidos.

Em razão desses aspectos, as teleadaptações de Jorge Amado cumprem seu papel social e mantêm sua atualidade ao propor em suas narrativas mulheres resilientes que visibilizam os espaços nordestinos em seus enfrentamentos cotidianos. Ao criar protagonistas donas de si, o escritor sugere uma nova forma de pensar o feminino, com mulheres livres e formadoras de suas opiniões em sintonia com as transformações do nosso tempo, sugerindo identidades e promovendo reconhecimentos a partir de seus lugares de fala. Portanto, as telenovelas analisadas provocam novas perspectivas de debate sobre as questões de gênero e instigam as mulheres a se libertarem dos estigmas e opressões, criando novos modos resistência e múltiplos espaços de sororidade.

\section{Referências}

ALVES, Branca Moreira; PITANGUY, Jacqueline. O que é feminismo. 5. ed. São Paulo: Brasiliense, 1985.

BATLIWALA, Srilatha (1994). "The meaning of women's empowerment: new concepts from action". In. G. Sen, A. Germain \& L.C.Chen (eds.). Population policies reconsidered: health, empowerment and rights, pp.127-138. Boston: Harvard University Press. 
BATLIWALA, Srilatha. Grassroots movements as transnational actors: Implications for global civil society. Voluntas: International Journal of Voluntary and Nonprofit Organizations, v. 13, n. 4, p. 393-409, 2002.

BELLINE, Ana Helena Cizotto. Representações do feminino. In: Caderno de Leituras: a literatura de Jorge Amado. São Paulo: Companhia das Letras, 2008.

BUTLER, Judith. Problemas de gênero: feminismo e subversão da identidade. Trad.: Renato Aguiar. Rio de Janeiro: Editora Civilização Brasileira, 2003.

COUTINHO, Carlos Nelson. Cultura e sociedade no Brasil: ensaios sobre ideias e formas. São Paulo: Expressão Popular, 2011.

FERREIRA, Ceiça. Memórias visuais sobre mulheres negras na recepção fílmica. Contemporânea, v. 16, n. 2, p. 389-407, 2018.

FREIRE, Paulo; SHOR, Ira. Medo e ousadia. Rio de Janeiro: Paz e Terra, 1986.

FREYRE, Gilberto. Sobrados e mucambos: decadência do patriarcado rural e desenvolvimento do urbano. In: SANTIAGO, Silviano. (Coord.). Intérpretes do Brasil. 2. ed. Rio de Janeiro: Nova Aguilar, 2002.

GABRIELA. Direção: Mauro Mendonça Filho; Roberto Talma. Brasil. Rede Globo, 2012. Telenovela (55 min).

GODOY, Arilda Schmidt. Pesquisa qualitativa: tipos fundamentais. Revista de Administração de empresas, p. 20-29, 1995.

GOFFMAN, Erving. Estigma: notas sobre a manipulação da identidade. Tradução: Mathias Lambert, v. 4, Rio de Janeiro: LTC, 1988.

HANCIAU, Nubia. A representação da mulata na literatura brasileira: estereótipo e preconceito. Cadernos Literários. Rio Grande: Ed. da FURG, v. 7, p. 57-64, 2002.

JODELET, Denise. Représentations sociales: un domaine en expansion. In:

(dir.). Les représentations sociales. 4 ed. Paris: Presses Universitaires de France, 1994.

LOPES, Maria Immacolata Vassalo de. Televisões, nações e narrações: para uma revisão das identidades culturais em tempos de globalização. Revista USP, n. 61, p. 30-39, 2004.

LOPES, Maria Immacolata Vassalo de. Corpo, gênero e sexualidade: um debate contemporâneo na educação. Petrópolis: Vozes, 2010.

MILLETT, Kate. Sexual Politics. New York: Columbia University Press, 1969.

MINAYO, Maria Cecilia de Souza. O desafio do conhecimento. 12 $2^{\mathrm{a}}$ ed. São Paulo: Editora Hucitec; 2011.

MOTTA, Luiz Gonzaga. Análise crítica da narrativa. Brasília: Editora UNB, 2013.

NAGAMINI, Eliana. Literatura, televisão, escola: estratégias para leitura de adaptações. São Paulo: Cortez, 2004. 
RAGO, Margareth. Epistemologia feminista, gênero e história. Masculino, feminino, plural. Florianópolis: Mulheres, 1998.

RIBEIRO, Djamila. O que é lugar de fala? Belo Horizonte (MG): Letramento: Justificando, 2017.

REBOUÇAS, Roberta de Almeida e. Telenovela, história, curiosidades e sua função social. In: ENCONTRO NACIONAL DE HISTÓRIA DA MÍDIA, 7., 2009, Fortaleza. Anais... Fortaleza, CE: Associação Brasileira de Pesquisadores de História da Mídia, 2009.

RONSINI, Veneza Mayora. Telenovelas e a questão da feminilidade de classe. MATRIZes, v. 10, n. 2, p. 45-60, 2016.

SIFUENTES, Lírian; RONSINI, Veneza. O que a telenovela ensina sobre ser mulher? Reflexões acerca das representações femininas. FAMECOS: mídia, cultura e tecnologia, v. 18, n. 1, p. 131-146, 2011.

TIETA. Direção: Reinaldo Boury; Ricardo Waddington; Luiz Fernando Carvalho. Brasil. Rede Globo, 1989-1990. Telenovela (60 min). 